situation, the judge may send the jurors back for further deliberation. The possibilities of prejudice are great. ${ }^{65}$ This may be a further reason for permitting waiver in the Patton situation but not in the Hibdon case.

\title{
IV
}

Hibdon v. United States conflicts with the Patton doctrine that any element of the jury can be waived. The Louisiana and Oregon constitutional and statutory provisions indicate that unanimity is not necessary to guarantee proof beyond a reasonable doubt. Another possible interpretation of the Hibdon case is that unanimity is an essential element of due process because it is part of the prosecutor's traditional burden of persuasion. But other courts have indicated a contrary view. In addition, other elements in the legal system indicate that unanimity is not as pervasive or essential as is commonly supposed. On constitutional grounds, then, waiver of unanimity is not distinguishable from waiver of other procedural guarantees and should be permitted.

The possibility is slight that the defendant guided by intelligent counsel will waive unanimity. Most waivers would be coerced by the fear of prejudice. Since this possibility is ever present, waiver of unanimity should not be permitted under any circumstances. This would be a just and reasonable rule of administration for the federal courts. ${ }^{68}$

${ }^{65}$ At this point waiver of unanimity is distinguishable from waiver of other elements. It is unlikely that refusal to waive other elements will cause frustrating delay as occurs when a jury is "hung."

* "Judicial supervision of the administration of criminal justice in the federal courts implies the duty of establishing and maintaining civilized standards of procedure and evidence.... Considerations of large policy in making the necessary accommodations in our federal system are wholly irrelevant to the formulation and application of proper standards for the enforcement of the federal criminal law in the federal courts." McNabb v. United States, 318 U.S. 332,340 (1943).

\section{THE EN BANC PROCEDURES OF THE UNITED STATES COURTS OF APPEALS}

In each of the eleven Federal Judicial circuits there is established a United States Court of Appeals composed of from three to nine circuit judges. ${ }^{1}$ It has been the custom of the courts of appeals in trying cases to divide into panels of three judges. In 1941, however, the Supreme Court in Commissioner of Internal Revenue v. Textile Mills Securities Corporation ${ }^{2}$ ruled that the judges of the courts of appeals had the power to convene all of the active circuit judges to try

162 Stat. 870 (1948), 28 U.S.C.A. $\$ 43$ (1949). There are three circuit judges in the First and Fourth Circuits; five in the Tenth; six in the Second, Fifth, Sixth, and Seventh; seven in the Third, Eighth, and Ninth; nine in the District of Columbia Circuit.

In addition to the circuit judges of the circuit any other circuit or district judge in the country and any supreme court justice appointed to the circuit are competent to hear cases in any court of appeals. 28 U.S.C.A. $\$ \$ 42,292$ (a) (1949).

314 U.S. 326 (1941), aff'g 117 F. 2d 62 (C.A. 3rd, 1940). 
cases. This power was explicitly recognized by Congress in $\S 46(\mathrm{c})$ of the Judicial Code adopted in 1948:

Cases and controversies shall be heard and determined by a court or division of not more than three judges, unless a hearing or rehearing before the court in banc is ordered by a majority of the circuit judges of the circuit who are in active service. A court in banc shall consist of all active circuit judges of the circuit. ${ }^{3}$

The Supreme Court in the Western Pacific Railroad case ${ }^{4}$ held that $\$ 46$ (c) -gave the courts of appeals only the power to sit en banc and left the procedure by which such a hearing or rehearing was to be held entirely up to the discretion of each court. But by reason of its "general power to supervise the administration of justice in the federal courts," the Supreme Court held that litigants must be permitted to petition for en banc sessions. ${ }^{6}$ While otherwise expressly authorizing the courts of appeals to develop their own procedures, the Court stipulated that these procedures must be clearly explained. ${ }^{7}$

Before considering the procedures, however, it is necessary to ascertain the

362 Stat. 871 (1948), 28 U..S.C.A. $\$ 46(c)$ (1949). The Court of Appeals' opinion and the Supreme Court opinion in the Textile Mills case, cited note 2 supra, present detailed and interesting accounts of the history of the courts of appeals (or the circuit courts of appeals as they were called until 1948). In the course of a rigorous statutory analysis the courts found the composition of the circuit courts of appeals to be ambiguous. Section 117 of the Judicial Code of March 3, 1911, c. 231, 36 Stat. 1087 (effective January 1, 1912), created the circuit courts of appeals and stated that they were to consist of three judges each. Congress apparently intended that the courts should be staffed by men who had been judges of the circuit courts which the Judicial Code abolished, but it omitted to include such a provision. The ambiguity arises because in some circuits they were more than three circuit judges. The circuit courts of appeals from their inception, however, convened in panels of three judges to decide cases. The courts in the Textile Mills case held that $\S 118$ did give the circuit courts of appeals the power to convene all the circuit judges and sit en banc. Previously the Ninth Circuit had stated briefly that the Circuit Court of Appeals had no such power. Lang's Estate v. Commissioner, 97 F. 2d 867 (C.A. 9th, 1938).

${ }_{4}^{4} 345$ U.S. 247 (1953), reported below sub nom. Western Pacific Railroad Corp. v. Western Pacific Railroad Co., 197 F. 2d 994 (C.A. 9th, 1953). The Supreme Court opinion was written by Chief Justice Vinson, Justice Frankfurter concurring specially. Justice Jackson dissented.

On remand the petition for rehearing en banc was denied, 205 F. 2d 934 (C.A. 9th, 1953), see note 28 infra, and subsequent petition for certiorari on the merits was also denied, 346 U.S. 910 (1953). The substantive issue involved in the case was a complicated bankruptcytax question; the amount involved was $\$ 21,000,000$.

5345 U.S. 247, 260 (1953), citing United States v. National City Lines, 344 U.S. 573, 589 (1948).

${ }^{6}$ Neither Justice Frankfurter nor Justice Jackson favored this practice.

7 "We hold that the statute is simply a grant of power to order hearings and rehearings en banc and to establish the procedure governing the exercise of that power. We hold that litigants are given no statutory right to compel each member of the court to give formal consideration to an application for a rehearing en banc. We hold that the statute does not compel the court to adopt any particular procedure governing the exercise of the power; but whatever the procedure which is adopted, it should be clearly explained, so that the members of the court and litigants in the court may become thoroughly familiar with it; and further, whatever the procedure which is adopted, it should not prevent a litigant from suggesting to those judges who, under the procedure established by the court, have the responsibility of initiating a rehearing en banc, that his case is an appropriate one for the exercise of the power." 345 U.S. 247, 267 (1953). 
reasons for establishing the en banc device. ${ }^{8}$ Experience has shown that en banc proceedings are "necessary and useful" to the efficient operation of any court of appeals composed of more than three judges. En banc hearings and rehearings are concerned primarily with resolving conflicts within a circuit. ${ }^{10}$ It sometimes happens that two panels within the same court of appeals have different views on a particular issue thus creating conflict and uncertainty. ${ }^{11}$ When disagrecing panels of the court are sitting simultaneously, the success of a litigant's case will depend "on the chance of the assignment calendar."12 The divergence is a natural result of the panel organization and can be corrected by a simple device: the court can be convened en banc to resolve the conflict by a ruling of a majority of the circuit judges. The en banc procedure may also be indicated in the rare instances where the judges are acquainted with the subject matter of a case before it is heard, and where it appears that a majority of the court is likely to reach a different result than a panel. Although resolving conflicts is the primary function of en banc proceedings, it is conceivable that the judges might also wish to use the device in "cases extraordinary in scale-either because the amount involved is stupendous or because the issues are intricate enough to invoke the pooled wisdom of the circuit."13

En banc hearings and rehearings must be employed, however, only in the

8 "'The principal utility of determinations by the courts of appeals in banc is to enable the court to maintain its integrity as an institution by making it possible for a majority of its judges always to control and thereby to secure uniformity and continuity in its decisions, while panels of three judges hear and decide the vast majority and time-saving procedure of having within the court." Maris, Hearing and Rehearing Carity of cases as to which no division exists

For further discussion on the utility and ing Cases In Banc, 19 F.R.D. 91 (1933). en banc, reflecting the purpose behind $\$ 46(\mathrm{c})$, see H.R. Rep. No. 1246, 77th Cong. 1st Sess.
(1941); Hearings before a Subcommittee of the Senate 77th Cong. 1st Sess. 39-40 (1941). See af the Senate Committee on the Judiciary on S.1053, (1938) p. 23; ibid., (1939) pp. 15, 16; Report of Annual Report of the Attorney General Judges 7 (1940). The opinions in the Textile Mills case, 314 U.S. 326 (1941) of Senior Circuit Pacific case, 345 U.S. 247 (1953), also discuss the case, 314 U.S. 326 (1941), and the Western

9345. U.S. 247, 260 (1953).

${ }^{10}$ See, e.g., the opinion of Justice Frankfurter, ibid., at 270.

"Just what constitutes a conflict is not, of course, always clear, since litigants normally attempt to show that their case is either within or without the confines of a prior precedent. While intra-circuit conflicts could theoretically be resolved by the Supreme Court in the same manner as inter-circuit conficts, certiorari does not ordinarily issue for this purpose. But see Maggio v. Zeitz, 333 U.S. 556 (1948). It would create greater expense to the litigants and would place additional burdens on the already crowded docket of the Supreme Court. See generally Kirkham and Robertson, Jurisdiction of the Supreme Court of the United States
$\$ 336$ (Wolfson and Kurland ed., 1951).

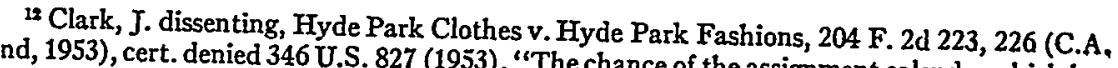
so operated against the plaintiff might 827 (1953). "The chance of the assignment calendar which has most recent cases on this issue before us easily have brought it success, to judge by the three

in this category; see note 4 supra. 
limited situations indicated by their purposes lest they retard the effective administration of the courts and create in fact a separate appellate court which is not established by statute. An en banc rehearing must not be used as a "hybrid intermediate court"14 causing delay and expense interposed between the three judge panel and the Supreme Court merely because the litigant wants another review. Congress has given the litigant no right to a proceeding before more than three circuit judges..$^{15}$ The courts of appeals in their inception were courts of three judges. ${ }^{16}$ Additional members have been appointed to the courts not because the three judge panels were thought to be inadequate, but because a rotation system or a second panel was necessary to relieve three men of the burden of steadily increasing litigation. ${ }^{17}$ Hence, even in a circuit with more than three judges, the panel is not a fragment of the court; it is the court with respect to a particular case. ${ }^{18}$

While everyone who has concerned himself with en banc proceedings agrees with the above rationale, ${ }^{19}$ neither Congress nor the courts have expressly delimited the situations in which en banc sessions may be held. ${ }^{20}$ The decision is entirely within the judges' discretion in the individual case. These courts which have adopted en banc procedures, however, have ordered relatively few en banc hearings or rehearings ${ }^{21}$ and have carefully restricted those to cases which are clearly within the purposes mentioned. ${ }^{22}$

${ }^{14}$ The Western Pacific Railroad case, 345 U.S. 247, 273 (1953), Justice Jackson dissenting.

${ }_{15}$ "We do not recognize that any litigant has a right to have a six judge court." Chief Judge Hutcheson, of the Fifth Circuit; quoted by the clerk of the court in a letter of November 17,1953 to the writer.

${ }^{16}$ See note 3 supra.

${ }^{17}$ For statistics on the increase of litigation in the courts of appeals see the Annual Report of the Administrative Office of the United States Courts.

${ }^{18}$ Some state statutes authorize their supreme courts also to meet in panels to hear cases. The panels there, however, are used primarily as time saving devices and are admittedly only fragments of the court. A panel is usually composed of a majority of the judges, and it is frequently provided that if one judge dissents, the case will be heard en banc. See, e.g., Code of Ala. (1940) tit. 13, § 13; Ark. Stat. Ann. (1947) §§ 22-200; Fla. Stat. (1951) § 25.08. See note 20 infra.

${ }^{19}$ See authorities cited in note 8 supra.

${ }^{20}$ Compare the state statutes which require the supreme court to sit en banc for the consideration of constitutional questions. See Ark. Stat. Ann. (1947) $\$ \S 22-200$.

${ }^{21}$ The Fifth Circuit sits once or twice a year. In 1952 the Eighth Circuit received two petitions for rehearing en banc, but these were denied and the court considered a few other matters en banc; the Ninth Circuit receives two or three petitions each year which are rarely granted. Letters to the Review from the clerks of the respective circuits of November, 1953.

In 1952 the District of Columbia Circuit, however, considered eleven cases en banc. See the Western Pacific Railroad case, 197 F. 2d 994, 1020 at 1021 (C.A. 9th, 1953).

2 Some en banc proceedings which have been held because of an intra-circuit conflict are: Oughton v. National Labor Relations Board, 118 F. 2d 486 (C.A. 3d, 1940); Dougherty Co. v. United States, 207 F. 2d 626 (C.A. 3d, 1953); United States ex rel. Robinson v. Johnson, 118 F. 2d 998 (C.A. 9th, 1941); Hopper v. United States, 142 F. $2 d 167$ and 181 (C.A. 9th, 1942 and 1944); Stewart v. Overholser, 186 F. 2d 339 (App. D.C., 1950); Kephart v. Kephart, 
With the functions of en banc hearings in mind, we may examine the procedures adopted..$^{23}$ The Courts of Appeals for the First and Fourth Circuits, having only three circuit judges are not concerned with en banc hearings. The Courts of Appeals in the Second, Sixth, and Seventh Circuits have no en banc procedures and do not meet en banc. ${ }^{24}$ There are only six circuits, then, which have adopted procedures for en banc sessions. All provide that before a case is assigned to a panel by the clerk, a majority of the active circuit judges may order a case to be heard en banc. This rarely occurs because the judges know about a case before it has been heard by the panel only if it has aroused a great amount of publicity. In the Ninth Circuit, however, the judges must approve the clerk's assignment of cases to the calendar and so do come into contact with the cases, but it is a matter of dispute whether they know enough about them at this stage to determine whether they should be heard en banc. ${ }^{25}$

Once the case has been assigned to a panel, all of the courts provide that a majority of the judges may order a hearing en banc at any time before the judgment is handed down. Normally, however, those judges who are not on the original panel will be unfamiliar with the case, and hence will have no occasion

193 F. 2d 677 (App. D.C., 1951); Columbia National Bank v. District of Columbia, 195 F. 2d 942 (App. D.C., 1952). For some of those that have been held because the case was especially important, see: Textile Mills case, 314 U.S. 326 (1941) (internal revenue deduction); Alton v. Alton, 207 F. 2d 667 (C.A. 3d, 1953) (constitutionality of Virgin Islands divorce act); Overholser v. Boddie, 184 F. 2d 240 (App. D.C., 1950) (writ of habeas corpus to secure release from mental institution); Matter of J. W. Carter, 192 F. 2d 15 (App. D.C., 1951) (license for bail bondsman); Columbia National Bank of Washington v. District of Columbia, 195 F. 2d 942 (App. D.C., 1952) (internal revenue); Citizens Bank v. District of Columbia, 195 F. 2d 946 (App. D.C., 1952) (internal revenue); Quinn v. United States, 203 F. $2 d 20$ (App. D.C., 1952) (contempt of congressional inquiry); Emspak v. United States, 203 F. 2d 54 (App. D.C., 1952) (contempt of congressional inquiry). See generally Independent Lead Mines Co. v. Kingsbury, 175 F. 2d 983 (C.A. 3d, 1941), and Bradley Mining Co. v. Boice, 198 F. 2d 790,792 (C.A. 9th, 1952).

In some of these cases it is difficult to determine whether an en banc proceeding was ordered because of conflict or because of the importance of the matter.

${ }^{23}$ The information about the particular procedures of the courts of appeals was obtained from the court rules and letters from the clerks of the respective courts. Some of these procedures have not been officially incorporated into the rules. For a comprehensive account of the procedure in the Third Circuit, see the article by Judge Maris, op. cit. supra note 8; the District of Columbia procedure is described in a letter from the Chief Judge of that Circuit to Chief Judge Denman of the Ninth Circuit and is reprinted in the Western Pacific Railroad case, 197 F. 2d 994, 1020-21 (C.A. 9th, 1953).

${ }^{24}$ The Sixth Circuit did sit en banc once during the war in a case which involved the death penalty for the crime of treason. Stephan v. United States, 133 F. 2d 87 (C.A. 6th, 1943).

In several opinions Judge Clark has criticized the practice of the Second Circuit never to sit en banc. See Lopinsky v. Hertz Drive-Ur-Self Systems, 194 F. 2d 422, 426 (C.A. 2d, 1951); Hyde Park Clothes v. Hyde Park Fashions, 204 F. 2d 223 (C.A. 2d, 1953); In re Sacher, 206 F. 2d 358, 361 (C.A. 2d, 1953), cert. granted 346 U.S. 894 (1953). In the latter case Judge Frank also favored an en banc hearing. Ibid., at 366.

${ }^{25}$ Compare the opinion of Judge Healy in the Western Pacific Railroad case, 197 F. 2d 994, 1013 at 1014 (C.A. 9th, 1953), with the emphatic negative by Chief Judge Denman: "Our tentative decision would require divine omniscience." Tbid., at 1019. 
to recognize the need for a hearing. The Third, Fifth, Ninth, and District of Columbia Circuits provide that any member of the panel who feels that the case should be heard en banc may consult the other circuit judges. ${ }^{26}$ In the Third and Ninth Circuits no formal procedure is followed. In the Fifth Circuit the panel judge presents the matter to the Chief Judge who will contact the other members of the court if he agrees to the en banc hearing. Under the District of Columbia practice, the judge addresses a memorandum to all the circuit judges. . It will be noticed, however, that under all of these arrangements, the other judges are acquainted with the case before the decision is handed down only if a member of the panel proposes an en banc hearing. The Third Circuit has attempted to correct this situation by requiring the judge who prepares the court's opinion in each case to circulate a draft of the opinion among all the circuit judges. Each judge on the court is thus familiarized with every case before it is decided. Then, if a majority of the circuit judges wish to hear a case en banc, they may so order. ${ }^{27}$

Even after a decision is handed down, a majority of the entire court may on its own motion order a rehearing en banc. ${ }^{28}$ Of the circuits which sit en banc all but the Ninth permit the initiative for such a rehearing to come from the judges not participating in the decision of the case. Usually, however, the impetus for rehearings en banc comes by petition from the party defeated in the original hearing. As has been noted, the Supreme Court in the Western Pacific Railroad case ruled that a litigant must be allowed to petition for an en banc proceeding but did not determine to what group within the court such petition must be addressed. A petition for rehearing en banc in the Third, Tenth, and District of Columbia Circuits is considered by all the circuit judges. In the Fifth Circuit the panel considers the petition, but if any of the members thinks a rehearing en banc is warranted, he contacts the Chief Judge, who if he agrees, convenes the other active circuit judges to vote on the petition. Under the curious procedure recently adopted by the Ninth Circuit, two steps are necessary before the case can come to the attention of the full court. The original panel must first grant a rehearing and then must independently determine the advisability of holding

${ }^{26}$ The Eighth and Tenth Circuit practice in this regard is nowhere stated.

${ }^{27}$ See Maris, op. cit. supra note 8 , at p. 93 . This procedure would eliminate the "serious strains in the court" which may be created by one panel's overruling the recent decision of another panel as described by Judge Clark: "Such freedom from the confines of precedent is confusing not only to the public, but also to colleagues who have no notice of the impending doom before it appears in print. It is made possible by the practice of this circuit never to sit in banc, ... though it does violate the precepts, recounted by Cotton Mather as agreed upon by the governor and magistrates, 'that one magistrate shall not cross the proceedings of another, without first advising him." "Lopinsky v. Hertz Drive-Ur-Self System, 194 F. 2d 422,429 (C.A. 2d, 1951).

Circulation of the panel's opinion is also recommended by Justice Frankfurter, 345 U.S. 247,268 at 271 (1953).

${ }^{28}$ Fed. Rules Civ. Proc. 59(d). If the court should order a case to be reheard en banc, it certainly should notify the parties that they will be arguing to all of the circuit judges, not to three of them. 
this rehearing en banc. If the panel determines either of these issues adversely to the petitioners, a majority of the entire circuit will never have the opportunity to consider an en banc hearing. ${ }^{29}$ The Eighth Circuit differs from the other circuits by giving the original panel the final authority to grant or deny any request for an en banc proceeding. Although such an arrangement is not inconsistent with the Supreme Court's mandate in the Western Pacific Railroad case, it tends to undermine the purposes of en banc hearings. A case should be reheard en banc only if the entire court might render a decision different from that of the panel or if a majority of the circuit judges think the case is particularly important. The only way to ascertain the opinions of a majority of the circuit judges is to consult them directly. ${ }^{30} \mathrm{~A}$ judge not on the panel is not unduly burdened, for it docs not take him long to become sufficiently familiar with a case to determine whether or not it should be heard en banc, and the cases he would be asked to consider would be few in number.

While each circuit is free to adopt that en banc procedure which is most convenient and efficient for its particular organization, all courts of appeals should adopt some procedure. It would appear that the Supreme Court has obligated the courts of appeals to employ the en banc power; ${ }^{31}$ in view of the important advantages afforded by this device, its use is certainly advisable. The extent to which these advantages will be realized is dependent on the specific procedure adopted; in order to effectuate the purposes of en banc hearings with a minimum of administrative difficulty the following suggestions are presented:

1. The court should adopt a rule clearly defining the instances in which en banc proceedings will be held, that is, in cases of conflict or extreme importance.

2. The order for an en banc session must come from a majority of the circuit judges.

3. Any member of the panel and any circuit judge not on the panel may propose an en banc session for the approval of a majority of the circuit judges.

${ }^{29}$ Rule 23 of the Ninth Circuit states: "Should a majority of the court as so constituted grant a rehearing and either from a suggestion of a party or upon its own motion be of the opinion that the case should be reheard en banc, they shall so inform the Chief Judge. The Chief Judge shall thereupon convene the active judges of the court and the court shall thereupon determine whether the case shall be reheard en banc." The rule, which was the Ninth Circuit's response to the Supreme Court's reversal in the Western Pacific Railroad case, see 205 F. 2d 374 (C.A. 9th, 1953), appears to be contrary to the holding in that case which stipulated that the panel should consider a rehearing en banc apart from the question of whether or not the panel should rehear the case. The appellant in Bradley Mining Co. v. Boice, 345 U.S. 932 (1953) (remanded by the Supreme Court after its Western Pacific decision), so argued on motion for rehearing en banc, which was denied, 205 F. 2d 937 (C.A. 9th, 1953), and on petition for certiorari which was also denied, 346 U.S. 874 (1953).

so See note 26 supra.

1345 U.S. 247, 260 (1953), and see note 7 supra. Judge Clark has so interpreted the decision, In re Sacher, 206 F. 2d 358, 362 (C.A. 2d, 1953), cert. granted 346 U.S. 894 (1953), but a majority of the Second Circuit denied a hearing en banc in that case and the Supreme Court's limited grant of certiorari did not include the en banc point. From its action in this case and in Bradley Mining Co. v. Boice, 345 U.S. 932 (1953), it would appear that the Supreme Court has decided to leave the matter of en banc proceedings, temporarily at least, at rest. See note 29 supra. 
4. The panel judge preparing the opinion will circulate a draft of his opinion among all the.circuit judges.

5. The litigant may petition all the circuit judges for an en banc hearing at the time the appeal is filed. He may also petition the panel for a rehearing en banc after the decision is given. ${ }^{32}$ The panel must consider the motion for a rehearing en banc apart from that for a rehearing by the original panel. ${ }^{33}$

A majority of the full court should have the opportunity to order an en banc session any time in order to avoid a decision which would not represent the view of the entire court. That provision would be complemented by the adoption of the Third Circuit's practice of circulating a draft of the panel's opinion, which seems best suited to acquaint all the judges with the issues in a case. While only a majority of all the judges should be able to grant petitions for rehearings en banc, these should be addressed to the original panel, any member of which might then bring the matter to the attention of the whole court if he so chooses. If no member of the panel believes that an en banc rehearing is warranted, the petition could be denied without reference to the whole court since the litigant does not have the right to address all the circuit judges after his case has been assigned to a panel. Each Court of Appeals would thus have the advantage of litigants' suggestions for the use of a procedure which is primarily intended for its own benefit without the administrative burden which consideration of each petition by the full Court would entail.

32 Considering the reasons for which en banc procedures should be granted, it may be argued that a litigant should be allowed to petition for a rehearing en banc only if the panel has departed from a precedent and has itself created a conflict, for he knows about a prior conflict or the importance of his case before the original hearing. On the other hand, for tactical reasons the litigant's attorney is hard put to decide whether or not he should suggest that his case is important enough for an en banc session.

The panel should have final disposition over a motion for rehearing and should be able to deny a petition for a rehearing en banc or to grant it subject to the approval of a majority of the circuit judges. If the litigant were given the right to petition all of the circuit judges after his case has been assigned to a panel, a new appellate court would be created between the three judge panel and the Supreme Court, a court which has no statutory existence. See page 450 supra.

${ }^{33}$ See note 28 supra. This would appear to be the mandate of the Supreme Court in the Western Pacific Railroad case, 345 U.S. 247, 262 (1953). It may be psychologically difficult, however, for the panel to consider the two questions separately. Hence, it would be wise to allow any member of the panel rather than a majority of the panel to recommend it to the other circuit judges.

\section{TRUST APPORTIONMENT OF CORPORATE DISTRIBUTIONS FROM FIXED ASSETS}

Rights of the life beneficiary and remainderman of a stock trust to corporate distributions have repeatedly presented difficult problems. ${ }^{1}$ The typical trouble-

1 Trusts, whose res consists of stock in wasting asset corporations or in trading corporations, such as those primarily engaged in the purchase and sale of real estate, are not discussed herein because as to such corporations, a different disposition, as between life beneficiary and 